\title{
New spectrophotometric methods for the determination of nifedipine in pharmaceutical formulations
}

\author{
Nafisur Rahman ${ }^{\bowtie}$ and Syed Najmul Hejaz Azmi \\ Department of Chemistry, Aligarh Muslim University, Aligarh, India; ${ }^{\circledR}$-mail: cht17nr@yahoo.co.in
}

Received: 22 March, 2005; revised: 06 October, 2005; accepted: 29 October, 2005

available on-line: 07 November, 2005

\begin{abstract}
Two simple, sensitive and economical spectrophotometric methods were developed for the determination of nifedipine in pharmaceutical formulations. Method A is based on the reaction of the nitro group of the drug with potassium hydroxide in dimethyl sulphoxide (DMSO) medium to form a coloured product, which absorbs maximally at $430 \mathrm{~nm}$. Method B uses oxidation of the drug with ammonium molybdate and subsequently reduced molybdenum blue is measured at $830 \mathrm{~nm}$. Beer's law is obeyed in the concentration range of 5.0-50.0 and 2.5-45.0 $\mathrm{g} \mathrm{m}^{-1}$ with methods A and B, respectively. Both methods have been successfully applied for the assay of the drug in pharmaceutical formulations. No interference was observed from common pharmaceutical adjuvants. The reliability and the performance of the proposed methods are established by point and interval hypothesis tests and through recovery studies.
\end{abstract}

Keywords: nifedipine, potassium hydroxide, ammonium molybdate, pharmaceutical formulations, validation, spectrophotometry

Nifedipine, dimethyl-1,4-dihydro-2,6-dimethyl-4-(2-nitrophenyl)pyridine 3,5-dicarboxylate is a calcium channel blocker that inhibits the transmembrane influx of $\mathrm{Ca}^{+2}$ into cardiac muscle cells and vascular smooth muscle through specific ion channels (Miller, 1987; Murdoch \& Brogden, 1993; Martindale, 2002). It decreases vascular peripheral resistance (Delgado \& Remers, 1991) for which it is widely used in the treatment of hypertension, angina pectoris and various other cardiovascular disorders (Stone et al., 1980). The drug and its formulations are official in The United States Pharmacopoeia (USP, 2000) and British Pharmacopoeia (BP, 1993), which recommend HPLC and non-aqueous titration for its assay, respectively.

The drug has been determined by a variety of analytical techniques such as high performance liquid chromatography (Zhang et al., 2001; Wang et al., 2002; Niopas \& Daftsios, 2003), high performance thin layer chromatography (Patravale et al., 2000), gas chromatography (Tu et al., 1995; Qin et al., 2000), micellar electrokinetic chromatography (Bretnall \& Clarke, 1995), electroanalytical methods (Dumitrescu et al., 2001), flow injection analysis (Richter et al.,
1997), mass spectrometry (Kumazawa et al., 1993) and UV spectrophotometry (Vyas \& Goswami, 1993; Yuan \& Zhu, 1996).

The estimation of nifedipine alone was carried out using second-order derivative spectra (Umapathi, 1994) of the compound in $0.1 \mathrm{M} \mathrm{HCl}$ whereas first derivative spectra were utilized for its assay in combined dosage forms (El-Walily, 1997). A methanolic solution of the drug reacts with 4-dimethylaminobenzaldehyde resulting in the formation of yellow-coloured product, which forms a basis for its determination at $380 \mathrm{~nm}$ (Mahadik et al., 1991). Two spectrophotometric methods have been recommended, one is based on the formation of blue-coloured complex with Folin Ciocalteau reagent (Sastry et al., 1997), and the second method involves the charge transfer complex formation with chloranil (Golcu \& Serin, 1998). A kinetic spectrophotometric method has also been described based on the oxidation of the drug with $\mathrm{KMnO}_{4}$ at neutral $\mathrm{pH}$ (Rahman \& Azmi, 1999). Two other spectrophotometric methods were developed in which the $-\mathrm{NO}_{2}$ group of nifedipine was reduced with $\mathrm{Zn} / \mathrm{NH}_{4} \mathrm{Cl}$ and $\mathrm{Zn}$ / $\mathrm{HCl}$ to hydroxylamino and primary aromatic amino

Abbreviations: BP, British Pharmacopoeia; DMSO, dimethyl sulphoxide; HPLC, high performance liquid chromatography; ICH, International Conference on Harmonisation; LOD, limit of detection; LOQ, limit of quantitation; TLC, thinlayer chromatography; USP, United States Pharmacopoeia. 
derivatives, respectively (Karadi et al., 2000; Rahman \& Hoda, 2002). The hydroxylamino derivative was reacted with 4-(methylamino)phenol and potassium dichromate to give a coloured chromophore, which absorbed maximally at $525 \mathrm{~nm}$ while the primary aromatic amino derivative formed Schiff's base with 3,4,5-trimethoxybenzaldehyde which was subsequently determined at $365 \mathrm{~nm}$. Extractive spectrophotometric methods have also been reported for the estimation of the drug in pharmaceutical preparations which are based on the coloured complex of the drug with reagents like bromocresol green, bromophenol blue, bromothymol blue and eriochrome black-T (Rahman et al., 2004).

This paper describes two simple and sensitive spectrophotometric methods for the determination of nifedipine in pharmaceutical formulations. Method $\mathrm{A}$ is based on the reaction of the nitro group of the drug with potassium hydroxide in dimethyl sulphoxide to form a coloured product peaking at 430 $\mathrm{nm}$. Method B uses the oxidation of the drug with ammonium molybdate, which subsequently reduced to molybdenum blue, is measured at $830 \mathrm{~nm}$. The proposed methods are validated as per the guidelines of the International Conference on Harmonisation (ICH, 1995).

\section{MATERIALS AND METHODS}

Apparatus. The absorbance measurements were made on a Spectronic $20 \mathrm{D}^{+}$spectrophotometer (Milton Roy, USA) with $1 \mathrm{~cm}$ matched glass cells. A water bath shaker was used to control the temperature for colour development. An Elico model Li-10 $\mathrm{pH}$ meter was used for $\mathrm{pH}$ measurements.

Reagents and standards. All chemicals used were of analytical or pharmaceutical grade. A 0.05 $\mathrm{M} \mathrm{KOH}$ (Merck, India) solution was prepared in tertiary butyl alcohol (Qualigens, India). A $0.02 \mathrm{M}$ ammonium molybdate (Merck, India) solution was prepared by dissolving $2.472 \mathrm{~g}$ of ammonium molybdate in $100 \mathrm{ml}$ of $4 \mathrm{M}$ sulphuric acid. Buffer solutions ranging from $\mathrm{pH}$ 2.4-5.6 were prepared by mixing $1.24-11.60 \mathrm{ml}$ of $0.2 \mathrm{M}$ disodium hydrogen phosphate and $18.76-8.40 \mathrm{ml}$ of $0.1 \mathrm{M}$ citric acid in $20 \mathrm{ml}$ (Britton, 1942). Reference standard of pure nifedipine and a nifedipine nitrosophenyl pyridine analog were kindly provided by J.B. Chemicals and Pharmaceuticals Ltd. (Mumbai, India) and Novartis Pharmaceuticals Ltd. (Mumbai, India), respectively. Commercially formulated tablets such as Nicardia Retard (J.B. Chemicals), Calciguard (Torrent), and Adalat Retard (Bayer) were purchased from local market. Standard solutions of 0.1 and $0.05 \%$ nifedipine were prepared in DMSO and methanol, respectively, and kept in dark.
Preparation of degraded nifedipine. A standard solution of pure nifedipine $\left(1.0 \mathrm{mg} \mathrm{ml}^{-1}\right)$ was exposed to diffused sunlight (natural) for $2 \mathrm{~h}$. A sample of $8.0 \mu \mathrm{l}$ of this solution and simultaneously the same amount of the nifedipine nitrosophenyl pyridine analog reference standard were spotted on a thin layer chromatographic plate of silica gel G (Merck, India) which was then developed in a mobile phase using chloroform/ethyl acetate/cyclohexane (19:2:2, by vol.) and observed under UV lamp. Two spots were present having the same $R_{f}$ value (0.5), thus it can be suggested that the degraded product of nifedipine is nifedipine nitrosophenyl pyridine (Pietta et al., 1981).

Method A: Recommended procedure for the determination of nifedipine. Aliquots of $0.05-0.5 \mathrm{ml}$ of standard drug solution $(0.1 \%)$ of nifedipine were pipetted into a series of $10.0 \mathrm{ml}$ standard volumetric flasks. Then, $0.6 \mathrm{ml}$ of $0.05 \mathrm{M} \mathrm{KOH}$ solution was added into each flask and diluted to $10.0 \mathrm{ml}$ with DMSO. The contents of each flask was mixed well at room temperature $\left(25 \pm 1^{\circ} \mathrm{C}\right)$ and the absorbance was measured at $430 \mathrm{~nm}$ against the reagent blank prepared similarly within the stability time period of $2 \mathrm{~h}$. The concentration of nifedipine was calculated either from a calibration curve or regression equation.

Method B: Recommended procedure for the determination of nifedipine. Into a series of boiling test tubes, different volumes $(0.1-0.9 \mathrm{ml})$ of $0.05 \%$ nifedipine were pipetted. To each test tube $1.4 \mathrm{ml}$ of $0.02 \mathrm{M}$ ammonium molybdate and $5.0 \mathrm{ml}$ of phosphate/citric acid buffer solution ( $\mathrm{pH} 4)$ were added, mixed well and heated in a water bath at $100 \pm 1^{\circ} \mathrm{C}$ for $20 \mathrm{~min}$. After heating, the solutions were cooled at room temperature and transferred to $10.0 \mathrm{ml}$ standard volumetric flasks and diluted to volume with doubly distilled water. The absorbance was measured within the stability time period of $4 \mathrm{~h}$ at $830 \mathrm{~nm}$ against the reagent blank treated similarly. The amount of the drug in a given sample can be calculated from a calibration graph or regression equation.

Procedure for the assay of nifedipine in pharmaceutical formulations. Two portions of powdered tablets equivalent to 50.0 and $25.0 \mathrm{mg}$ of nifedipine were weighed accurately, and separately extracted into $50.0 \mathrm{ml}$ chloroform with shaking, and the residues were filtered using Whatmann No. 42 filter paper. The filtrates were evaporated to dryness under vacuum and the corresponding residues were dissolved in DMSO and methanol, respectively, and transferred to $50.0 \mathrm{ml}$ standard volumetric flasks and diluted to volume with their corresponding solvents. The assay was completed following the recommended procedures for determination of nifedipine. 


\section{RESULTS AND DISCUSSION}

Nitro compounds are known to give interesting colours with alkali in different polar media. It has been suggested that the reactions of nitro aromatic compounds with alkali in acetone, alcohol, $N, N^{\prime}$-dimethylforamide or DMSO (Porter, 1955; Maiti et al., 1982) yield nitroquinoid ions. Nifedipine contains a nitro group attached to the benzene ring, which reacts with $\mathrm{KOH}$ in DMSO medium to produce coloured nitroquinoid ion which absorbs maximally at $430 \mathrm{~nm}$ (Fig. 1A). The coloured chromophore formed was found to be negatively charged as it was adsorbed on anion exchange resin beads. Therefore, based on the literature background and our experimental findings the reaction mechanism was proposed and is given in Scheme 1.

Ammonium molybdate $\left(\mathrm{Mo}^{\mathrm{VI}}\right)$ behaves as an oxidizing agent in acidic medium and is reduced to molybdenum blue $\left(\mathrm{Mo}^{\mathrm{V}}\right)$ on treatment with reducing

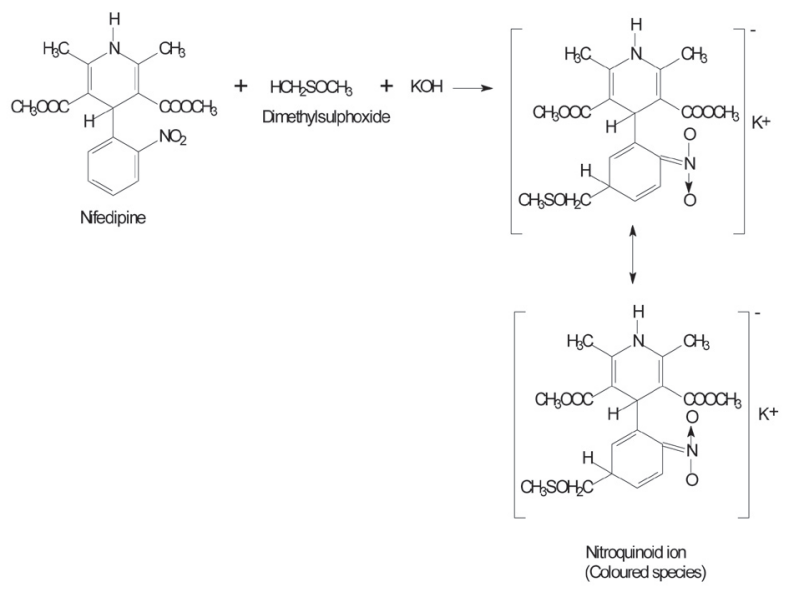

Scheme 1.

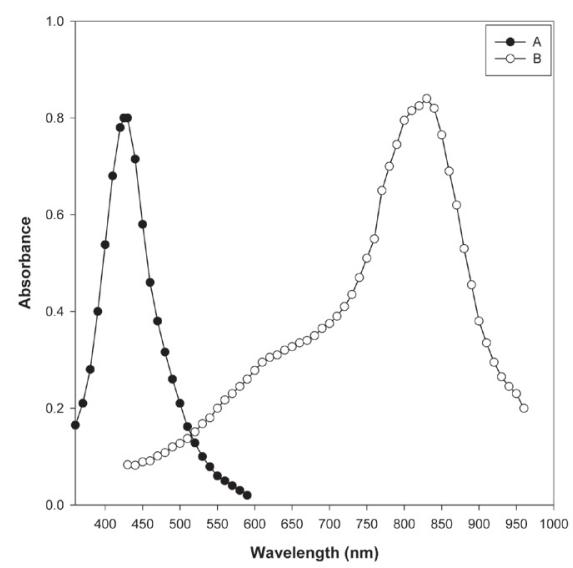

Figure 1. Absorption spectra of coloured products of nifedipine.

(A) $25 \mu \mathrm{g} \mathrm{ml}-1$ nifedipine $+0.6 \mathrm{ml}$ of $0.05 \mathrm{M} \mathrm{KOH}$ in DMSO medium; (B) $20.0 \mu \mathrm{g} \mathrm{ml}^{-1}$ nifedipine $+1.4 \mathrm{ml}$ of $0.02 \mathrm{M}$ ammonium molybdate $+5.0 \mathrm{ml}$ of $\mathrm{pH} 4.0$ phosphate/citric acid buffer solution. substances. This property is exploited for the spectrophotometric determination of nifedipine which reduces $\mathrm{Mo}^{\mathrm{VI}}$ to $\mathrm{Mo}^{\mathrm{V}}$ showing maximum absorbance at $830 \mathrm{~nm}$ (Fig. 1B).

\section{Optimization of variables and method development}

The concentration of different reagents used for method development was optimized by performing a series of experiments.

\section{Method A: Effect of $\mathrm{KOH}$}

The influence of the volume of $0.05 \mathrm{M} \mathrm{KOH}$ on the intensity of the colour developed at constant nifedipine concentration $\left(30.0 \mu \mathrm{g} \mathrm{ml}^{-1}\right)$ was examined in the range $0.05-0.6 \mathrm{ml}$ of $0.05 \mathrm{M} \mathrm{KOH}$. It is clear from Fig. 2A that the maximum absorbance was attained with $0.4 \mathrm{ml}$ of $0.05 \mathrm{M} \mathrm{KOH}$; above this volume the absorbance remained unchanged. Therefore, $0.6 \mathrm{ml}$ of $0.05 \mathrm{M} \mathrm{KOH}$ was used in all further measurements.

\section{Method B: Effect of heating}

To study the effect of heating time for the development of maximum colour for method B, $0.4 \mathrm{ml}$ of $0.05 \%$ nifedipine was mixed with $1.5 \mathrm{ml}$ of 0.02 $\mathrm{M}$ ammonium molybdate and $5 \mathrm{ml}$ of buffer solution. The contents of the mixture were heated for up to $23 \mathrm{~min}$ at $100 \pm 1^{\circ} \mathrm{C}$. The intensity of the colour developed was measured at room temperature $\left(25 \pm 1^{\circ} \mathrm{C}\right)$ after dilution to $10.0 \mathrm{ml}$ with doubly distilled water. It is apparent from this investigation that the maximum intensity of colour was obtained after 18 min of heating and remained constant up to $23 \mathrm{~min}$. Therefore, the optimum heating time was fixed at $20 \mathrm{~min}$.

\section{Method B: Effect of the concentration of ammonium molybdate}

The effect of the volume of $0.02 \mathrm{M}$ ammonium molybdate on the colour development was investigated by adding different volumes $(0.50-1.5 \mathrm{ml})$ of $0.02 \mathrm{M}$ ammonium molybdate to $200 \mu \mathrm{g}$ of nifedipine. It was found that the maximum absorbance of the blue colour was reached with $1.2 \mathrm{ml}$ of the reagent, and remained constant with higher volumes (Fig. 2). Therefore, $1.5 \mathrm{ml}$ of the reagent was used throughout the experimental investigations.

\section{Method B: Effect of $\mathrm{pH}$}

The influence of $\mathrm{pH}$ on the development of colour was studied using disodium hydrogen phosphate/citric acid buffer. The maximum colour intensity was observed in the $\mathrm{pH}$ range of 3.4-4.6 (Fig. 3) 


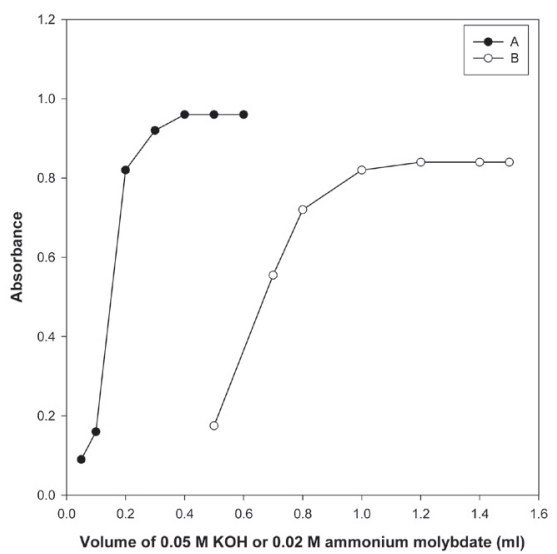

Figure 2. Effect of the volume of (A) $0.05 \mathrm{M} \mathrm{KOH}$ (method A) and (B) $0.02 \mathrm{M}$ ammonium molybdate (method B).

and therefore $5 \mathrm{ml}$ of $\mathrm{pH} 4$ buffer solution was used throughout the experiment.

\section{Specificity}

The specificity of the proposed methods were evaluated by determining the concentration of nifedipine in the presence of varying amounts of degraded product of nifedipine such as nifedipine nitrosophenyl pyridine. It was found that the degraded product did not react with either of the reagents utilized in methods A and B. There was no interference from the common excipients such as sodium stearyl fumarate, magnesium stearate, starch, lactose and talc present in tablets

\section{Solution stability}

The solution stability of the reference drug and tablet solutions was monitored by keeping the solutions at room temperature $\left(25 \pm 1^{\circ} \mathrm{C}\right)$ under darkness for several days and then recording the absorption spectra of the solutions and also by performing

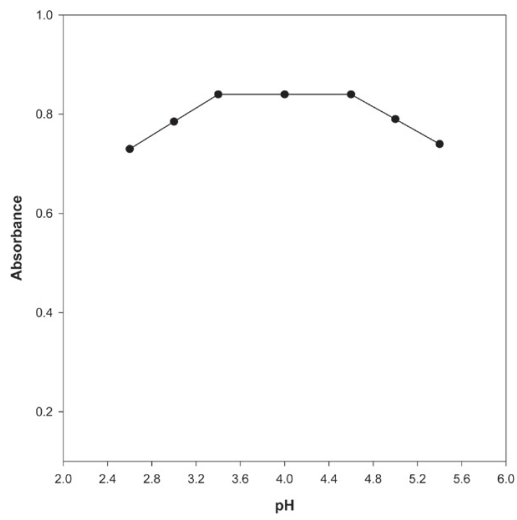

Figure 3. Effect of $\mathrm{pH}$ of disodium hydrogen phosphate/ citric acid buffer solution.

$20.0 \mu \mathrm{g} \mathrm{ml}^{-1}$ nifedipine $+1.4 \mathrm{ml}$ of $0.02 \mathrm{M}$ ammonium molybdate $+5.0 \mathrm{ml}$ buffer of different $\mathrm{pH}$ values.
TLC analysis. There was no change in the absorption spectra of reference and sample solutions for at least seven days. The band corresponding to the degradation product of nifedipine was not observed under UV lamp. A single spot at $R_{\mathrm{f}}$ value of 0.3 was obtained on TLC plate using silica gel $G$ as stationary phase and chloroform/ethyl acetate/cyclohexane (19:2:2, by vol.) as mobile phase.

\section{Robustness}

Each operational parameter was closely examined and challenged for the robustness of the proposed methods. The operational parameters investigated were as follows:

For Method A

- $0.6 \mathrm{ml}$ of $0.05 \mathrm{M} \mathrm{KOH}$

For Method B

- $1.5 \mathrm{ml}$ of $0.02 \mathrm{M}$ ammonium molybdate

- $5 \mathrm{ml}$ of buffer solution of $\mathrm{pH} 4$

- 20 min heating time

- cooling at room temperature

The robustness of the proposed methods relative to each operational parameter was evaluated by analyzing the contents of nifedipine tablets under variable experimental conditions. A sample solution containing $40 \mu \mathrm{g} \mathrm{ml}^{-1}$ of active drug (Nicardia retard-10) was assayed five times using both methods. The results showed a mean recovery \pm relative standard deviation of $100.11 \pm 0.16 \%$ and $100.06 \pm 0.15 \%$ for methods A and B, respectively. Thus the operational conditions for the proposed methods to determine nifedipine in tablet formulations were found to be very robust.

\section{Analytical data}

Under the optimized experimental conditions, calibration graphs were constructed by plotting the absorbance against the concentration of nifedipine. Beer's law was obeyed in the concentration range 5.0-50.0 and 2.5-45.0 $\mu \mathrm{g} \mathrm{ml} \mathrm{m}^{-1}$ with molar absorption coefficients of $1.108 \times 10^{4}$ and $1.455 \times 10^{4} \mathrm{l} \mathrm{mol}^{-1}$ $\mathrm{cm}^{-1}$ for methods $A$ and $B$, respectively. Table 1 summarizes the optical characteristics and the results of statistical analysis of the experimental data such as linear regression equations for methods $\mathrm{A}$ and $\mathrm{B}$ along with correlation coefficient, standard deviation of slope $\left(S_{b}\right)$ and intercept $\left(S_{\mathrm{a}}\right)$, confidence interval of slope $\left(t S_{\mathrm{b}}\right)$ and intercept $\left(t S_{\mathrm{a}}\right)$, detection limit and quantitation limit. The limit of detection (LOD) and quantitation (LOQ) were calculated using the following relation (Ermer, 2001)

$$
\mathrm{LOD}=3.3 \times S_{0} / b \text {, and LOQ }=10 \times S_{0} / b
$$

where $S_{0}$ is the standard deviation of the calibration curve and $b$ is the slope. The small value of variance suggested negligible scatter of experimental data points around the line of regression. 
Table 1. Optical and regression characteristics of the proposed methods

\begin{tabular}{|c|c|c|}
\hline Parameters & Method A & Method B \\
\hline$\lambda_{\max }(\mathrm{nm})$ & 430.0 & 830.0 \\
\hline $\begin{array}{l}\text { Beer's law limit } \\
\left(\mu \mathrm{g} \mathrm{ml} \mathrm{m}^{-1}\right)\end{array}$ & $5.0-50.0$ & $2.5-45.0$ \\
\hline $\begin{array}{l}\text { Molar absorp- } \\
\text { tion coefficient } \\
\left(1 \mathrm{~mol}^{-1} \mathrm{~cm}^{-1}\right)\end{array}$ & $1.108 \times 10^{4}$ & $1.455 \times 10^{4}$ \\
\hline $\begin{array}{l}\text { Linear regression } \\
\text { equation a }\end{array}$ & $\begin{array}{l}\mathrm{A}=1.010 \times 10^{-3}+ \\
3.195 \times 10^{-2} \mathrm{C}\end{array}$ & $\begin{array}{c}\mathrm{A}=5.900 \times 10^{-4}+ \\
4.197 \times 10^{-2} \mathrm{C}\end{array}$ \\
\hline$S_{\mathrm{a}}$ & $1.110 \times 10^{-3}$ & $4.197 \times 10^{-2}$ \\
\hline$t S_{\mathrm{a}}^{\mathrm{b}}$ & $2.716 \times 10^{-3}$ & $1.224 \times 10^{-3}$ \\
\hline$S_{\mathrm{b}}$ & $3.000 \times 10^{-5}$ & $2.000 \times 10^{-5}$ \\
\hline$t S_{\mathrm{b}}{ }^{\mathrm{C}}$ & $7.341 \times 10^{-5}$ & $4.894 \times 10^{-5}$ \\
\hline $\begin{array}{l}\text { Correlation coef- } \\
\text { ficient }(\mathrm{r})\end{array}$ & 0.9999 & 0.9999 \\
\hline Variance $\left(\mathrm{S}_{0}{ }^{2}\right)$ & $2.250 \times 10^{-6}$ & $5.625 \times 10^{-7}$ \\
\hline $\begin{array}{l}\text { Detection limit } \\
\left(\mu g \mathrm{ml}^{-1}\right)\end{array}$ & 0.155 & 0.059 \\
\hline $\begin{array}{l}\text { Quantitation } \\
\text { limit }\left(\mu \mathrm{g} \mathrm{ml} \mathrm{m}^{-1}\right)\end{array}$ & 0.470 & 0.179 \\
\hline
\end{tabular}

a With respect to $\mathrm{A}=\mathrm{a}+\mathrm{bC}$, where $\mathrm{C}$ is the concentration $\left(\mu \mathrm{g} \mathrm{ml} \mathrm{l}^{-1}\right)$ and $\mathrm{A}$ is absorbance. ${ }^{\mathrm{b}}$ Confidence interval of the intercept at $95 \%$

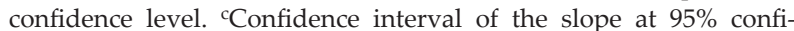
dence level.

The accuracy and precision of the proposed methods (A and B) was evaluated by performing five replicate determinations of nifedipine in pure forms at three different concentrations (10, 30 and $45 \mu \mathrm{g} \mathrm{ml}^{-1}$ ) by short term (intra day) and daily (inter day) precisions (Table 2). The standard analytical errors, relative standard deviations and recoveries obtained in the intra day and inter day analyses for methods A and B were found to be acceptable. Thus the proposed methods are effective for the determination of nifedipine.

The accuracy of the proposed methods was also checked by performing recovery experiments through standard addition technique. For this purpose, a known amount of pure nifedipine was added to pre-analyzed dosage forms and then determined by the recommended procedures. The results (Table 3) showed that the mean recovery and relative standard deviation were in the range of 99.97-100.17 and $0.15-0.52 \%$ for method $\mathrm{A}$ and $100.03-100.10$ and $0.12-0.24 \%$ for method B, respectively. No interference from the common excipients was observed.

Table 4 shows a comparison of the performance of the proposed methods with that of other existing UV-visible spectrophotometric methods. It is clear from the table that the proposed methods are sensitive with acceptable values of relative standard deviations. Thus the proposed methods can compete with other existing methods in the determination of the drug at lower concentrations.

The proposed methods were tested on tablet formulations and the results are presented in Table 5. The results (Table 5) of the proposed methods ( $\mathrm{A}$ and $\mathrm{B}$ ) were compared with those of the reference method (Rahman \& Hoda, 2002) using point hypothesis tests. The results in the table show that the calculated paired $\mathrm{t}$ - and F-values are less than the theoretical ones (Christian, 1994) confirming no significant difference between the performance of the proposed methods and the reference method at 95\% confidence level. The interval hypothesis tests (Hartmann et al., 1955) were also performed to judge the performance of the proposed methods and the results are summarized in Table 6 . The Canadian

Table 2. Evaluation of the accuracy and precision of the proposed methods by intra day and inter day assay

\begin{tabular}{|c|c|c|c|c|c|}
\hline \multirow[t]{2}{*}{ Proposed methods } & \multicolumn{2}{|c|}{$\begin{array}{l}\text { Amount } \\
\left(\mu \mathrm{g} \mathrm{ml} l^{-1}\right)\end{array}$} & \multirow[t]{2}{*}{$\begin{array}{l}\text { Recovery } \pm \text { RSD }^{a} \\
(\%)\end{array}$} & \multirow[t]{2}{*}{$\mathrm{SAE}^{\mathrm{b}}$} & \multirow[t]{2}{*}{ C.L. ${ }^{c}$} \\
\hline & Taken & Found \pm S.D. ${ }^{a}$ & & & \\
\hline \multicolumn{6}{|l|}{ Method A } \\
\hline \multirow[t]{3}{*}{ Intra day assay } & 10.0 & $10.009 \pm 0.060$ & $100.09 \pm 0.60$ & 0.027 & 0.075 \\
\hline & 30.0 & $30.053 \pm 0.041$ & $100.18 \pm 0.14$ & 0.018 & 0.051 \\
\hline & 45.0 & $45.033 \pm 0.046$ & $100.07 \pm 0.10$ & 0.021 & 0.058 \\
\hline \multirow[t]{3}{*}{ Inter day assay } & 10.0 & $10.015 \pm 0.080$ & $100.15 \pm 0.78$ & 0.036 & 0.099 \\
\hline & 30.0 & $30.072 \pm 0.046$ & $100.24 \pm 0.15$ & 0.021 & 0.058 \\
\hline & 45.0 & $45.026 \pm 0.065$ & $100.06 \pm 0.15$ & 0.029 & 0.081 \\
\hline \multicolumn{6}{|l|}{ Method B } \\
\hline \multirow[t]{3}{*}{ Intra day assay } & 10.0 & $10.007 \pm 0.052$ & $100.07 \pm 0.52$ & 0.023 & 0.065 \\
\hline & 30.0 & $30.026 \pm 0.062$ & $100.09 \pm 0.21$ & 0.028 & 0.077 \\
\hline & 45.0 & $44.990 \pm 0.046$ & $99.98 \pm 0.11$ & 0.021 & 0.057 \\
\hline \multirow[t]{3}{*}{ Inter day assay } & 10.0 & $10.012 \pm 0.049$ & $100.12 \pm 0.49$ & 0.022 & 0.061 \\
\hline & 30.0 & $30.041 \pm 0.064$ & $100.14 \pm 0.21$ & 0.029 & 0.080 \\
\hline & 45.0 & $44.985 \pm 0.052$ & $99.97 \pm 0.12$ & 0.023 & 0.065 \\
\hline
\end{tabular}

${ }^{a}$ Mean for five independent analyses; ${ }^{b}$ SAE, standard analytical error; ${ }^{c}$ C.L., confidence limit at $95 \%$ confidence level and four degrees of freedom $(t=2.776)$ 
Table 3. Determination of nifedipine in pharmaceutical formulations by standard addition technique

\begin{tabular}{|c|c|c|c|c|c|c|c|c|c|c|c|c|}
\hline \multirow{4}{*}{$\begin{array}{l}\text { Pharma- } \\
\text { ceutical } \\
\text { prepara- } \\
\text { tions }\end{array}$} & \multicolumn{6}{|c|}{ Method A } & \multicolumn{6}{|c|}{ Method B } \\
\hline & \multicolumn{3}{|c|}{ Amount } & \multirow{3}{*}{$\begin{array}{l}\text { Recove- } \\
\text { ry } \pm \\
\text { RSD } \\
(\%)^{\mathrm{a}}\end{array}$} & \multirow[t]{3}{*}{$\mathrm{SAE}^{\mathrm{b}}$} & \multirow[t]{3}{*}{ C.L. ${ }^{c}$} & \multirow{2}{*}{\multicolumn{3}{|c|}{$\begin{array}{l}\text { Amount } \\
\left(\mu \mathrm{g} \mathrm{ml}^{-1}\right)\end{array}$}} & \multirow{3}{*}{$\begin{array}{l}\text { Reco- } \\
\text { very } \pm \\
\text { RSD } \\
(\%)^{\mathrm{a}}\end{array}$} & \multirow[t]{3}{*}{$\mathrm{SAE}^{\mathrm{b}}$} & \multirow[t]{3}{*}{ C.L. ${ }^{c}$} \\
\hline & \multicolumn{3}{|c|}{$\left(\mu \mathrm{g} \mathrm{ml} \mathrm{l}^{-1}\right)$} & & & & & & & & & \\
\hline & Taken & Added & $\begin{array}{l}\text { Found } \\
\pm \mathrm{SD}^{\mathrm{a}}\end{array}$ & & & & Taken & Added & $\begin{array}{l}\text { Found } \\
\pm \mathrm{SD}^{\mathrm{a}}\end{array}$ & & & \\
\hline \multirow[t]{2}{*}{$\begin{array}{l}\text { Nicardia } \\
\text { retard-10 }\end{array}$} & 10.0 & 10.0 & $\begin{array}{l}20.012 \\
\pm 0.048\end{array}$ & $\begin{array}{l}100.06 \\
\pm 0.24\end{array}$ & 0.021 & 0.059 & 10.0 & 10.0 & $\begin{array}{l}20.015 \\
\pm 0.043\end{array}$ & $\begin{array}{l}100.07 \\
\pm 0.22\end{array}$ & 0.019 & 0.054 \\
\hline & 20.0 & 20.0 & $\begin{array}{l}40.069 \\
\pm 0.060\end{array}$ & $\begin{array}{l}100.17 \\
\pm 0.15\end{array}$ & 0.027 & 0.075 & 20.0 & 20.0 & $\begin{array}{l}40.038 \\
\pm 0.058\end{array}$ & $\begin{array}{l}100.10 \\
\pm 0.15\end{array}$ & 0.026 & 0.072 \\
\hline \multirow[t]{2}{*}{$\begin{array}{l}\text { Calcigu- } \\
\text { ard-10 }\end{array}$} & 10.0 & 10.0 & $\begin{array}{l}19.993 \\
\pm 0.052\end{array}$ & $\begin{array}{r}99.97 \\
\pm 0.52\end{array}$ & 0.023 & 0.064 & 10.0 & 10.0 & $\begin{array}{l}20.005 \\
\pm 0.049\end{array}$ & $\begin{array}{l}100.03 \\
\pm 0.24\end{array}$ & 0.022 & 0.061 \\
\hline & 20.0 & 20.0 & $\begin{array}{l}40.081 \\
\pm 0.065\end{array}$ & $\begin{array}{l}100.20 \\
\pm 0.16\end{array}$ & 0.029 & 0.081 & 20.0 & 20.0 & $\begin{array}{l}40.024 \\
\pm 0.047\end{array}$ & $\begin{array}{l}100.06 \\
\pm 0.12\end{array}$ & 0.021 & 0.058 \\
\hline \multirow[t]{2}{*}{$\begin{array}{l}\text { Adalat } \\
\text { retard-10 }\end{array}$} & 10.0 & 10.0 & $\begin{array}{l}20.031 \\
\pm 0.059\end{array}$ & $\begin{array}{l}100.15 \\
\pm 0.29\end{array}$ & 0.027 & 0.073 & 10.0 & 10.0 & $\begin{array}{l}20.015 \\
\pm 0.043\end{array}$ & $\begin{array}{l}100.07 \\
\pm 0.22\end{array}$ & 0.019 & 0.054 \\
\hline & 20.0 & 20.0 & $\begin{array}{l}40.044 \\
\pm 0.065\end{array}$ & $\begin{array}{l}100.11 \\
\pm 0.16\end{array}$ & 0.029 & 0.081 & 20.0 & 20.0 & $\begin{array}{l}40.024 \\
\pm 0.047\end{array}$ & $\begin{array}{l}100.06 \\
\pm 0.12\end{array}$ & 0.021 & 0.058 \\
\hline
\end{tabular}

${ }^{\mathrm{a}}$ Mean for five independent analyses; ${ }^{\mathrm{b} S A E}$, standard analytical error; ${ }^{\mathrm{c} C . L .}$., confidence limit at $95 \%$ confidence level and four degrees of freedom $(t=2.776)$

Table 4. Comparison of the proposed methods with existing spectrophotometric methods for the estimation of nifedipine in pharmaceutical formulations

\begin{tabular}{|c|c|c|c|c|c|c|}
\hline \multirow[t]{2}{*}{ Reagents } & $\lambda_{\max }$ & $\begin{array}{l}\text { Beer's law } \\
\text { limit }\end{array}$ & $\begin{array}{l}\text { Molar absorp- } \\
\text { tion coefficient }\end{array}$ & Recovery & RSD & References \\
\hline & $(\mathrm{nm})$ & $\left(\mu \mathrm{g} \mathrm{ml}^{-1}\right)$ & $\left(1 \mathrm{~mol}^{-1} \mathrm{~cm}^{-1}\right)$ & $(\%)$ & $(\%)$ & \\
\hline $\begin{array}{l}\text { Ethanol and phosphate } \\
\text { buffer saline }\end{array}$ & 340.0 & - & - & $99.70-99.90$ & - & Vyas \& Goswami, 1993 \\
\hline $\begin{array}{l}\text { 4-Dimethylaminobenzal- } \\
\text { dehyde }\end{array}$ & 380.0 & $5.0-60.0$ & - & $97.80-98.50$ & - & Mahadik et al., 1991 \\
\hline Potassium permanganate & 530.0 & $18.0-44.0$ & - & $99.50-101.30$ & 1.50 & Rahman \& Azmi, 1999 \\
\hline $\begin{array}{l}\text { 4-Methylaminophenol and } \\
\text { dichromate }\end{array}$ & 525.0 & $5.0-175.0$ & $1.900 \times 10^{3}$ & $99.70-100.50$ & 0.60 & Rahman \& Hoda, 2002 \\
\hline $\begin{array}{l}\text { 3,4,5-Trimethoxybenzalde- } \\
\text { hyde }\end{array}$ & 365.0 & $10.0-70.0$ & - & $100.20-102.40$ & 1.50 & Karadi et al., 2000 \\
\hline Bromocresol green & 415.0 & $5.0-32.5$ & $6.410 \times 10^{3}$ & $99.90-100.10$ & 0.82 & Rahman et al., 2004 \\
\hline Bromophenol blue & 415.0 & $4.0-37.5$ & $4.850 \times 10^{3}$ & $99.90-100.10$ & 0.72 & Rahman et al., 2004 \\
\hline Bromophenol thymol blue & 415.0 & $6.5-33.0$ & $5.260 \times 10^{3}$ & $99.80-100.90$ & 0.66 & Rahman et al., 2004 \\
\hline Eriochrome black $\mathrm{T}$ & 520.0 & $4.5-22.5$ & $7.690 \times 10^{3}$ & $100.00-100.20$ & 0.68 & Rahman et al., 2004 \\
\hline Potassium hydroxide & 430.0 & $5.0-50.0$ & $1.108 \times 10^{4}$ & $100.06-100.24$ & $0.10-0.78$ & This work \\
\hline Ammonium molybdate & 830.0 & $2.5-45.0$ & $1.455 \times 10^{4}$ & 99.97-100.14 & $0.10-0.52$ & This work \\
\hline
\end{tabular}

Table 5. Comparison of the proposed methods using point hypothesis tests with the reference method at $95 \%$ confidence level

\begin{tabular}{|c|c|c|c|c|c|c|c|c|c|c|}
\hline \multirow{2}{*}{$\begin{array}{l}\text { Pharmaceutical } \\
\text { preparations }\end{array}$} & \multicolumn{4}{|l|}{ Method A } & \multicolumn{4}{|l|}{ Method B } & \multicolumn{2}{|c|}{ Reference method } \\
\hline & Recovery & $\mathrm{RSD}^{\mathrm{a}}$ & $\begin{array}{l}\text { Paired } \\
\mathrm{t} \text {-value }{ }^{\mathrm{b}}\end{array}$ & $\begin{array}{l}\text { F-va- } \\
\text { lue }\end{array}$ & Recovery & $\mathrm{RSD}^{\mathrm{a}}$ & $\begin{array}{l}\text { Paired } \\
\text { t-value }\end{array}$ & F-value ${ }^{b}$ & Recovery & $\mathrm{RSD}^{\mathrm{a}}$ \\
\hline & $(\%)$ & $(\%)$ & & & $(\%)$ & $(\%)$ & & & $(\%)$ & $(\%)$ \\
\hline Nicardia retard-10 & 100.11 & 0.16 & 0.114 & 2.536 & 100.06 & 0.15 & 0.024 & 2.987 & 100.05 & 0.26 \\
\hline Calciguard-10 & 100.20 & 0.16 & 0.113 & 2.391 & 100.10 & 0.15 & 0.086 & 3.137 & 100.14 & 0.26 \\
\hline Adalat retard-10 & 100.17 & 0.15 & 0.412 & 1.718 & 100.10 & 0.15 & 0.111 & 1.828 & 100.05 & 0.20 \\
\hline
\end{tabular}

${ }^{a}$ Mean for five independent analyses; ${ }^{b}$ Theoretical t-value $(v=8)$ and F-value $(v=4,4)$ at $95 \%$ confidence level are 2.306 and 6.39 , respectively 
Table 6. Comparison of the proposed methods using interval hypothesis tests with the reference method at $95 \%$ confidence level

\begin{tabular}{lllll}
\hline $\begin{array}{l}\text { Pharmaceu- } \\
\text { tical } \\
\text { preparations }\end{array}$ & \multicolumn{2}{l}{ Method A } & \multicolumn{2}{l}{ Method B } \\
\cline { 2 - 5 } & $\begin{array}{l}\text { Lower } \\
\text { limit } \\
\left(\theta_{\mathrm{L}}\right)\end{array}$ & $\begin{array}{l}\text { Upper } \\
\text { limit }^{\mathrm{a}} \\
\left(\theta_{\mathrm{U}}\right)\end{array}$ & $\begin{array}{l}\text { Lower } \\
\text { limit }^{\mathrm{a}} \\
\left(\theta_{\mathrm{L}}\right)\end{array}$ & $\begin{array}{l}\text { Upper } \\
\text { limit }^{\mathrm{a}} \\
\left(\theta_{\mathrm{U}}\right)\end{array}$ \\
\hline $\begin{array}{l}\text { Nicardia re- } \\
\text { tard-10 }\end{array}$ & 0.986 & 1.016 & 0.985 & 1.015 \\
$\begin{array}{l}\text { Calciguard-10 } \\
\begin{array}{l}\text { Adalat re- } \\
\text { tard-10 }\end{array}\end{array}$ & 0.986 & 1.016 & 0.985 & 1.014 \\
\hline
\end{tabular}

${ }^{\text {a } A}$ bias, based on recovery experiments, of $\pm 2 \%\left(\theta_{\mathrm{L}}=0.98\right.$ and $\theta_{\mathrm{U}}=$ 1.02 ) is acceptable in pharmaceutical analysis.

Health Protection Branch has recommended that a bias of $\pm 2 \%\left(\theta_{L}=0.98\right.$ and $\left.\theta_{L}=1.02\right)$ based on recovery experiments (Canadian Health Protection Branch Guideline, 1992) is acceptable for pharmaceutical analysis. It is clear from the table that the true bias of all samples is less than $\pm 2 \%$.

\section{CONCLUSIONS}

The proposed methods are compared with other existing spectrophotometric methods and are found to be more sensitive with low values of relative standard deviations. The proposed methods do not require any pretreatment of the drug and tedious extraction procedure prior to its analysis. The newly developed methods are sensitive enough to enable quantitation of the drug at low concentrations. These advantages encourage the application of the proposed methods in routine quality control analysis of nifedipine in pharmaceutical formulations.

\section{Acknowledgements}

The authors are grateful to the Chairman, Department of Chemistry, Aligarh Muslim University, Aligarh for providing research facilities.

Financial assistance provided by Council of Scientific and Industrial Research (CSIR), New Delhi, India to Dr. Syed Najmul Hejaz Azmi (snhazmi@yahoo.com) as a Research Associate (Award No. 9/112 (329)/2002-EMR-I) is gratefully acknowledged.

The authors wish to express their gratitude to Messers J.B. Chemicals and Pharmaceuticals Ltd, (Mumbai, India) and Novartis Pharmaceuticals Ltd, (Mumbai, India) for providing samples of pure nifedipine and nifedipine nitrosophenyl pyridine analog, respectively.

\section{REFERENCES}

Bretnall AE, Clarke GS (1995) Investigation and optimization of the use of micellar electrokinetic chromatography for the analysis six cardiovascular drugs. J Chromatogr A 700: 173-178.

British Pharmacopoeia (1993) vol 1, p 449. Her Majesty Stationary Office, London.

Britton HTS (1942) Solutions of known hydrogen concentration. In Hydrgen Ions, vol I, p 304. Chapman and Hall Ltd, London.

Canadian Health Protection Branch Guideline (1992) In Acceptable methods. Ministry of National Health and Welfare, Canada Health Protection Branch, Ottawa, Canada.

Christian GD (2004) Data Handling, In Analytical Chemistry, 6th edn, p 90. John Wiley and Sons, Inc., Singapore.

Delgado JN, Remers WA (1991) Wilson and Gisvold's Text Book of Organic Medicinal and Pharmaceutical Chemistry, 9 edn, p 554. JB Lippincott Company, Philadelphia.

Dumitrescu V, David V, Pavel A (2001) Polarographic determination of nifedipine and chloramphenical. Rev Chim 52: 317-320.

El-Walily AFM (1997) Analysis of nifedipine-acebutolol hydrochloride binary combination in tablets using UVderivative spectroscopy, capillary gas chromatography and high performance liquid chromatography. J Pharm Biomed Anal 16: 21-30.

Golcu AY, Serin S (1998) Spectrophotometric determination of nifedipine via charge transfer complexes. Sci Pharm 66: 341-349.

Hartmann C, Smeyers-Verbeke J, Penninckx W, Heyden YV, Vankeerberghen P, Massart DL (1995) Reappraisal of hypothesis testing for method validation: Detection of systematic error by comparing the means of two methods or of two laboratories. Anal Chem 67: 44914499.

International Conference on Harmonisation (1995) ICH Harmonised Tripartite Guideline-Text on Validation of Analytical Procedures. Fed Regist 60: 11260.

Ermer J (2001) Validation in pharmaceutical analysis. Part I: An integrated approach. J Pharm Biomed Anal 24: 755-767.

Karadi AB, Ravi KUM, Shobha M, Raju S (2000) A spectrophotometric determination of nifedipine. East Pharm April: 117-118.

Kumazawa T, Sato K, Seno H, Suzuki O (1993) Positiveand negative-ion mass spectrometry and rapid extraction with sep-pak $\mathrm{C}_{18}$ cartridges for dihydropyridine calcium antagonists and their photodecomposition products. Hochudoku 11: 128-129.

Mahadik KR, Byale GB, More HN, Kadam SS (1991) A spectrophotometric method for estimation of nifedipine and its formulations. I Inst Chem 63: 218.

Maiti S, Patel BH, Pandya BM (1982) A simple method for analysis of nitrobenzene in aniline. Indian J Chem A 21: 279-281.

Martindale The Extra Pharmacopoeia (2002) 33rd ed, pp 940-946, Royal Pharmaceutical Society, London.

Miller RJ (1987) Multiple calcium channels and neuronal function. Science 235: 46-52.

Murdoch D, Brogden RN (1993) Sustained release nifedipine formulations: an appraisal of their current uses and prospective roles in the treatment of hypertension, ischaemic heart disease and peripheral vascular disorders. Drugs 46: 961-975. 
Niopas I, Daftsios AC (2003) Determination of nifedipine in human plasma by solid phase extraction and high performance liquid chromatography: validation and application to pharmacokinetic studies. J Pharm Biomed Anal 32: 1213-1218.

Patravale VB, Nair VB, Gore SP (2000) High-performance thin-layer chromatographic determination of nifedipine from bulk drug and from pharmaceuticals. J Pharm Biomed Anal 23: 623-627.

Pietta PG, Rava A, Biondi P (1981) High performance liquid chromatography of nifedipine, its metabolites and photochemical degradation products. J Chromatogr 210: 516-521.

Porter CC (1955) Color reaction for determination of some aromatic nitro compounds. Anal Chem 27: 805-807.

Qin Y, Liu H, He X, Zhuang H (2000) Determination of nifedipine in plasma by capillary gas chromatography. Shanghai Dier Yike Daxue Xuebao 20: 512-513.

Rahman N, Azmi SNH (1999) Method for determination of nifedipine in pure form and in pharmaceutical preparations. Acta Pharm 49: 113-118.

Rahman N, Hoda MN (2002) Spectrophotometric method for the determination of nifedipine with 4(methylamino)phenol and potassium dichromate. Il Farmaco 57: 435-441.

Rahman N, Khan NA, Azmi SNH (2004) Extractive spectrophotometric methods for the determination of nifedipine in pharmaceutical formulations using bromocresol green, bromophenol blue, bromothymol blue and eriochrome black T. Il Farmaco 59: 47-54.

Richter P, Toral MI, Quiroz G, Jaque P (1997) Flow-through polarographic cell for flow-injection analysis. Determi- nation of nifedipine in pharmaceutical formulations. Lab Rob Autom 9: 255-262.

Sastry CSP, Chintalapati R, Venkateswarlu R (1997) A simple spectrophotometric method for estimation of nifedipine. J Inst Chem 69: 187.

Stone PH, Antman EM, Muller JE, Braunwald E (1980) Calcium channel blocking agents in the treatment of cardiovascular disorders. Part II. Hemodynamic effects and clinical applications. Ann Inter Med 93: 886-904.

The United States Pharmacopoeia (2000) 24th ed, pp 1182 1185, Rockville, MD, USA.

Tu J, Peng J, Xin J, Liu G (1995) Determination of nifedipine in human plasma by gas chromatography-mass spectrometry, Zhonggno Yiyuan Yaoxue Zazhi 15: 197199.

Umapathi P (1994) Determination of atenolol, nifedipine, aspirin and dipyridamole in tablet preparations by second-order derivative spectrophotometry. Int I Pharm 108: 11-19.

Vyas SP, Goswami SK (1993) A sensitive visible spectrophotometric method for the estimation of nifedipine. Indian Drugs 30: 342-344.

Wang Z, Tang X, Hou J, Pan C, Wei X (1981) Quantitative determination of nifedipine and atenolol in sustainedrelease two-layer tablets by HPLC. Shenyang Yaoke Daxue Xuebao 19: 38-40.

Yuan G, Zhu B (1996) UV spectrophotometry of nifedipine tablets. Zhongguo Yiyao Gongye Zazhi 27: 171-172.

Zhang Y, Liu Z, Guo Y, Gu X (2001) Determination of nifedipine in human serum by micellar liquid chromatography. Zhongguo Yiyuan Yaoxue Zazhi 21: 152-153. 